Notre Dame Law School

NDLScholarship

1993

\title{
Erastian and Sectarian Arguments in Religiously Affiliated American Law Schools
}

Thomas L. Shaffer

Notre Dame Law School, thomas.I.shaffer.1@nd.edu

Follow this and additional works at: https://scholarship.law.nd.edu/law_faculty_scholarship

Part of the Legal Education Commons, and the Religion Law Commons

\section{Recommended Citation}

Thomas L. Shaffer, Erastian and Sectarian Arguments in Religiously Affiliated American Law Schools, 45 Stan. L. Rev. 1859 (1992-1993).

Available at: https://scholarship.law.nd.edu/law_faculty_scholarship/587

This Article is brought to you for free and open access by the Publications at NDLScholarship. It has been accepted for inclusion in Journal Articles by an authorized administrator of NDLScholarship. For more information, please contactlawdr@nd.edu. 


\title{
Erastian and Sectarian Arguments in Religiously Affiliated American Law Schools
}

\section{Thomas L. Shaffer*}

\begin{abstract}
Matthew's Jesus told his listeners not to worry about their material survival, not because he was summoning them to ascetic renunciation, but because their heavenly father knew their needs. "Seek first the righteousness of the Kingdom, and the rest will be thrown in," is a recipe not for poverty but for plenty. It may be similar when we ask how the value-laden subcommunity goes about caring about justice in the wider society. It may be the case not only by happenstance but by a deep inner logic, if God is God, that the subcommunity's fidelity to its own vocation will "contribute to state policy" more strongly-and certainly more authentically-than if they worried about compromising their principles in order to be effective.
\end{abstract}

John Howard Yoder $^{1}$

\section{INTRODUCTION}

The legal education establishment in the United States some time ago gave up discouraging religiously affiliated law schools. Its support for them now, however, is conditioned on their approaching religious affiliation in a manner that is seen as consistent with the dominant American attitude toward religion-that religion is a private affair and that public moral issues, including issues of jurisprudence and professional ethics, are secular issues, to be talked about in secular language, pursuant to secular principles, and in a secular style.

I begin here by considering the requirement of the American Bar Association, in its Standards for the Approval of Law Schools, that religiously affiliated law schools be diverse in faculty, staff, and student body. That requirement seems part of the secular condition, although it also seems to leave room for what I regard as a non-secular, theological response. Because the ABA's policy is (unwittingly, no doubt) theological, a theological re-

* B.A., J.D., LL.D.; Robert and Marion Short Professor of Law, University of Notre Dame; member of the Indiana Bar. The author was a member of the Accreditation Committee of the Council on Legal Education and Admissions to the Bar, American Bar Association, 1974-1980. I am grateful for the assistance with this essay of Nicholas Chase, Robert Cochran, John H. Garvey, Linda Harrington, Stanley Hauerwas, L. Gregory Jones, Robert E. Rodes, Jr., Nancy J. Shaffer, John Howard Yoder, and the editors of the Stanford Law Review.

1. On Not Being in Charge 10 (Sept. 25, 1992) (on file with the Stanford Law Review). 
sponse is possible. Indeed, the ABA's diversity requirement expresses (or at any rate parallels) a position similar to those taken within the religious groups that provide legal education, on what the people of God should be.

There are three positions in the Christian theology of legal education: that the presence of the Church in the civil community should be a secular presence; that its presence should be Erastian; and that its presence should be sectarian. I do not accept the secular position, and argue that the Erastian position tends to become, perhaps despite itself, secular. I tend to favor the sectarian position. I believe an ideal legal education conducted in the Church $^{2}$ would encourage distinct and religious views about the use of state power in the law and styles of lawyering.

\section{The ABA's Selectively Imposed Secular Theology}

During the ABA's consideration of the accreditation of the law school at Oral Roberts University in the 1970 s, the key requirement became the religious diversity of its staff, faculty, and student body. ${ }^{3}$ The ABA Accreditation Committee was then willing to countenance a law school run by vehement Oklahoma Fundamentalists ${ }^{4}$ only if the law school, like President

2. Throughout this paper, I capitalize "Church" when referring to Christians in general, and not when referring to a particular denomination, except, of course, for proper nouns. This arcane device emphasizes that Christians sometimes refer to themselves as the People of God, and thus to the Church, as what they are. See J. Robert Nelson, Church, in A HandBook of Christian TheOlogy: DEFINITION ESSAYS ON CONCEPTS AND MOVEMENTS OF THOUGHT IN CONTEMPORARY Protestantism 53, 53-54 (Arthur A. Cohen \& Marvin Halverson eds., 1958).

3. Thomas L. Shaffer, Background on 211, Syllabus, Nov. 1981, at 1, 6 (A.B.A. Section on Legal Education and Admissions to the Bar). Standard 211 now reads in pertinent part:

The law school shall maintain equality of opportunity in legal education, including employment of faculty and staff, without discrimination or segregation on ground of race, color, religion, national origin, or sex. ...

...

... This Standard does not prevent a law school from having a religious affiliation and purpose and adopting and applying policies of admission of students and employment of faculty and staff that directly relate to this affiliation and purpose.... These policies may provide a preference for persons adhering to the religious affiliation and purpose of the law school, but shall not be applied to preclude a diverse student body in terms of race, color, religion, national origin, or sex. This Standard permits religious policies ... only to the extent that they are protected by the United States Constitution. It shall be administered as if the First Amendment of the United States Constitution governs its application.

OfFice of the Consultant on Legal Education, American Bar Association, Standard FOR THE APPROVAL OF LAW SCHOOLS AND INTERPRETATIONS, Std. 211 (1992) [hereinafter STANDARD]. On the issue discussed in this paper, the ABA has taken the position that the Constitution does not preclude an accrediting agency's imposing a diversity requirement on a religious institution.

4. Like many other religious designations (e.g., "Anabaptist," "Methodist," "Jesuit," "Mormon"), "fundamentalist" was at first used, as Carnell uses it, as an epithet. Edward John Carnell, Fundamentalism, in A HANDBOOK OF ChRISTIAN TheOlOgY: DEFINITION EsSAYs ON CONCEPTS AND Movements of Thought in Contemporary Protestantism, supra note 2, at 142, 142-43 (a disapproving definition of fundamentalism). Carl F.H. Henry points to a historical definition derived from the "five points of fundamentalism" adopted at the Niagara Conference in 1895. These points are: (1) that Scripture is totally inerrant and entirely inspired; (2) that Jesus is God; (3) the virgin birth of Jesus; (4) "substitutionary atonement"; and (5) that Jesus rose physically from the grave. Carl F.H. Henry, Fundamentalist Ethics, in THE WESTMINSTER DICTIONARY OF CHRISTIAN ErHics 241-42 (James F. Childress \& John Macquarrie eds., 1986). The Oxford English Dictionary suggests that in the pejorative the word describes a religious movement that is zealous, ignorant, and 
Clinton's cabinet, was made to look like America and if its sponsoring university was willing to agree to the ABA's view of what a religiously affiliated law school should look like. This quasi-judicial position was not determinative in the case of Oral Roberts University; a federal lawsuit resulted in accreditation on constitutional grounds. ${ }^{5}$ But later, the general legislation under which the ABA accreditation process operates enshrined the requirement of diversity, an apparent elaboration of what the constitution requires. ${ }^{6}$

Prior to the Oral Roberts case, diversity was not a prominent issue in ABA accreditation proceedings. During ABA consideration of the law school at Brigham Young University, an institution of the Church of Jesus Christ of Latter Day Saints, the ABA did not see diversity as important, unlike other issues of religious discrimination. Brigham Young was willing to accept non-Mormon ${ }^{7}$ students and faculty if the non-Mormons in residence were willing to observe the church's rules as to liquor and coffee, among other things. ${ }^{8}$ Members of both the ABA Accreditation Committee and the ABA Council on Legal Education and Admissions to the Bar noisily debated whether a school could impose its religious code of conduct on students. Both bodies finally agreed to allow Brigham Young to do so, provided its code of conduct did not infringe on the morals of non-Mormons (and nobody could seem to locate a creed that requires coffee and liquor).

Nor was diversity prominent when the new Southern Baptist law schools at Campbell University and Mississippi College sought accreditation-perhaps because those schools, given their locations in Buies Creek, North Carolina, and Jackson, Mississippi, were already religiously as diverse as the communities around them. Diversity was apparently not an issue during accreditation of either older church-related and Jewish schools or the newer Roman Catholic schools in Dayton and Miami (St. Thomas). In these cases, the ABA either did not raise the issue, or the schools solved diversity issues by admissions and faculty appointment criteria that did not include statements of belief-something Oral Roberts was not willing to give up. More-

extremely conservative; but it also suggests a neutral connotation that describes a church with membership drawn from the lower middle class and a style of study and preaching devoted to biblical literalism. VI OXFoRd ENGLISH DictionARY 267 (2d ed. 1989).

5. Oral Roberts Univ. v. ABA, No. 81-C3171 (N.D. Ill. July 22, 1981) (order enjoining the $A B A$ "from denying provisional accreditation to ORU's Law School in whole or in part on the basis of ... prohibitions against religious restrictions"). Oral Roberts University later dismissed its complaint voluntarily. Id. The law school remained provisionally accredited until it moved to Regent University (formerly C.B.N. University), in Virginia Beach, Virginia. It is now called the Regent University School of Law (also known as the Regent University College of Law and Government) and claims to have been "approved by the American Bar Association since 1989." LAW SERvicES, THE OfFICIAL GUIDE To U.S. LAW Schools: 1993-94, at 292. The current Directory of Law Teachers does not list it in any category. See Association of AMERICAN Law Schools, AALS DIRECTORY OF LAW TEACHERS: 1992-93.

6. See STANDARD, supra note 3 ("This Standard permits religious policies . . . only to the extent that they are protected by the United States Constitution.").

7. "Mormon" is, in my experience, now a generally accepted reference for members of the Church of Jesus Christ of Latter Day Saints. See generally Anthony DePalma, Faith and Free Speech Wrestle for Dominance in Brigham Young Case, N.Y. TIMES, Mar. 10, 1993, at A11.

8. Frank S. Mead, Handbook of Denominations in the United States 95 (7th ed. 1985). 
over, in the wake of Oral Roberts, the ABA has not decided to impose retroactively a diversity requirement on older religiously affiliated law schools. For example, the ABA has not compelled the Jesuit schools at Fordham, Santa Clara, Boston College, or Georgetown to recruit nonCatholics into their faculties and student bodies.

The ABA's diversity requirement attempts to make law through exercise of governmental power. Acting with authority it gets from state court rules, the ABA decides which law school diplomas qualify people for licenses to practice law.9 A church sets up a law school. The ABA says the population of the church's law school must be diverse or its graduates cannot be lawyers. Although the ABA lost on this position against Oral Roberts in federal court, ${ }^{10}$ it has not ended its attempt to impose law with that case, nor has it abandoned its claim of respect for the Constitution. Its legislative rule now states: "This standard permits religious policies . . . only to the extent that they are protected by the United States Constitution."11 Diversity is required unless the federal constitution forbids the ABA from requiring diversity.

Whether the ABA realizes it or not, its position on diversity asserts a moral and theological argument by the lawyers, law teachers, and judges on the ABA Committee and Council. Proponents of the diversity rule argued that lawyers, like military officers, have to serve all sorts of people, and that their training should therefore, as in the military academies, be among all sorts of people. It would be dangerous, in their view, to learn to be a lawyer in a sectarian learning community. ${ }^{12}$ I want to focus on this theological reason, which is an ecclesiological ${ }^{13}$ reason-even though few in the ABA bureaucracy would admit that their view of what the Church ought to be is related to their support for the diversity requirement. ${ }^{14}$

But the argument is theological: The people of God should engage the power of government, business, and civic community by "working within the system" and by using the language, the style, and the principles of the

9. In 44 states, Guam, the Northern Mariana Islands, Puerto Rico, and the Virgin Islands, bar admission rules require that the applicant have a law degree from a school accredited by the American Bar Association. ABA, COMPREHENSIVE GUIDE TO BAR ADMISSION REQUIREMENTS, 19921993, at 10-11 (1992).

10. Oral Roberts Univ. v. ABA, No. 81-C3171 (N.D. Ill. filed June 8, 1981). For a further discussion of the case, see note 5 , supra.

11. STANDARD, supra note 3.

12. This fear stems from a particular view of sects:

A sect is understood to be a particular type of religious organization which, by combining and applying in a distinctive way theological doctrines that in themselves may be quite orthodox, forms small, intimate, exclusive, voluntary societies based on explicit faith; resistance to compromise with "the world"; participatory, protodemocratic, or populist leadership; and normative metaphysical-moral vision, demanding rigorous ethical standards.

Max L. Stackhouse, Sect, in The Westminster Dictionary of Christian Ethics, supra note 4, at $566,567$.

13. Ecclesiology is the branch of theology that deals with what the Church (ecclesia) should be.

14. On the claim that public policies favoring or imposing requirements of diversity are at bottom ecclesiological, see Philip Gleason, Speaking of Diversity: LaNGUage aNd ETHNicITY IN TWENTIETH-CENTURY AMERICA (1992). 
system within which it is attempting to work. The people of God should endeavor not to be distinct in such an engagement. This assumes that the civil or political community has developed a general or universal style, body of principles, and language, as distinguished from the particular principles, style, and language that the people of God can locate in their scriptures and in their tradition. Consequently, the civil community's particular positions, or particular descriptions of positions, do not merit general notice unless (and until) they are "validated" under criteria that are general or universal. (What appears to be civil consensus, however, is of course as particular as what the civil community identifies and rejects as particular. ${ }^{15}$ )

The argument for muting religiously distinct styles of education, as well as distinct principles and language in describing and arguing moral and political questions, also occurs in specifically theological dress within communities of belief. ${ }^{16}$ When played out in terms of consequences in the learning community-spirit among students, inevitable biases in teaching, and issues that dominate discussions in the lounges and in the law review-the argument seems to have three versions: secular, Erastian, and sectarian.

The ABA's treatment of Oral Roberts strongly suggests a theological preference for secularism over the others. Consequently, the ABA seems to have lent an imprimatur to the management of law schools one finds in state universities, where religion is generally regarded as something to be kept private. There, religious arguments in class or faculty meetings would, I suppose, be regarded as improper. Presumably, the ABA would similarly approve of religiously affiliated secular law schools, where such statements would be considered in bad taste and offensive to democratic moral values. ${ }^{17}$ When I was Dean of the Law School at Notre Dame, a bright, able student (who is now a judge) came to me to complain that the classroom walls had crucifixes on them, and that some of the faculty began their classes with prayers. I noted that was not particularly remarkable at Notre Dame, and

15. As John Howard Yoder puts it, discussing James M. Gustafson's recent tour de force on Christian religious ethics:

Gustafson ... joins academic apologetes ... who believe that there is ... just one ... accessible meaning system, and that it will be of service, both to the Christian tradition and to contemporary doubters, that we restate the former in such a way as to make sense to the latter.

$\cdots$

... [But] there is no non-particular place to stand. ... The theory of truth ... which can claim to put the "particularity" of others in a box only because it thinks that its own "necessary truths of reason" are universal[ is in fact no less in a box itself.

John Howard Yoder, On Not Being Ashamed of the Gospel: Particularity, Pluralism, and Validation, 9 FAITH \& PhIL. 285, 288-89 (1992) (discussing JAMES M. GustAFsOn, ETHICS FROM A THEOCENTRIC PERSPECTIVE (1981-1984)).

16. Yoder suggests that such communities move to the universal or general to avoid being vulnerable. Id. at 286-87. Law schools are certainly vulnerable to such things as the accrediting power of the ABA. See note 9 supra.

17. David Hollenbach, John H. Garvey \& Michael J. Perry are all developing arguments to the contrary in forthcoming papers. I am particularly indebted to Father Hollenbach. See David Hollenbach, Contexts of the Political Role of Religion: Civil Society and Culture (1992) (unpublished manuscript, on file with the Stanford Law Review). 
he replied, "But what about the separation of church and state?" I now think of that young man as having known more than he knew he knew.

\section{ERAStian AND Sectarian Alternatives to the ABA's SECULAR APPROACH}

Because both all non-denominational law schools and most-virtually all-religiously affiliated American law schools are secular, ${ }^{18}$ the remainder of this paper will address the two alternatives to the secular approach: Erastian and sectarian. These positions are basically opposed theological arguments. Under the Erastian position, the Church serves a civil society that remains, in important ways, Christian. Under the sectarian position, the pe-

18. Of $\mathbf{4 8}$ law schools in the U.S. that I believe to be church-related or Jewish, I estimate that 37 are functionally secular; seven are Erastian; and four are sectarian. These figures represent, of course, my solipsistic judgment about what these schools are doing, but making this distinction clarifies changing perceptions of the meaning of religious affiliation. See Thomas L. Shaffer \& Robert E. Rodes, Jr., A Christian Theology for Roman Catholic Law Schools, 14 U. DAYTon L. Rev. 5 (1988) (an Erastian argument for the most part aimed at this type of clarification). Steven $M$. Barkan traces the decline toward secularism of the largest single sub-group of religiously affiliated law schools in the United States, those under the sponsorship of the Roman Catholic Society of Jesus. Steven M. Barkan, Jesuit Legal Education: Focusing the Vision, 74 MARQ. L. REv. 99 (1990); see also Robert J. Araujo, Legal Education and Jesuit Universities: Mission and Ministry of the Society of Jesus?, 37 LOY. L. REv. 245 (1991). These articles sketch out further Erastian arguments for those schools, and others under Roman Catholic auspices. Roman Catholic political theology and jurisprudence tends toward Erastianism, partly because Roman Catholics are most clearly the heirs of the "integral Christendom" of the Middle Ages, but also because Catholic social teaching strives for a language that can be used with non-believers.

Jay Argones argues that the traditionally Catholic angle on natural law is appropriate course content in law schools under Roman Catholic auspices for two reasons: patriotic and catechetic. Jay J. Argones, Beyond Bork and Brennan: Should Catholic Law Schools Teach Natural Law?, CRISIS, November 1990, at 20. The combination makes the enterprise Erastian; an exclusive focus on catechesis would, I suppose, make the enterprise sectarian. For a broader application of these issues to Christian universities in the United States, see James Tunstead Burtchaell, The Decline and Fall of the Christian College (pts. 1-2), First ThIngs, April 1991, at 16, First ThINGS, May 1991, at 30.

Catholic law schools, Barkan says, early developed a distaste for being called sectarian and, from that resistance, tended to adopt secular models for teaching law. Barkan, supra, at 105-07. He nonetheless identifies the survival of what he calls the "distinctive spirit" of Jesuit education in the Jesuit law schools: "inspiration, motivation, values, attitudes, and style." Id. at 108. But, he argues, an American law school is not "primarily a religious community," which means that the religious infiuences he favors supporting in such schools become a force for unity or sometimes ecumenism in an Erastian enterprise. This force centers around three moral values: the dignity of the individual; the pervasive demand for justice; and particular attention to what Roman Catholic social teaching has come lately to call "the preferential option for the poor." Id. at 112-14. By contrast, a Jesuit school that sought to be sectarian (although $I$ know of none that does) would begin, I think, by saying that it is a religious community. It would not regard itself as an ecumenical community; and it would seek to preserve itself as what Yoder calls a communal instrument of moral reasoning, which is to say that it would observe rabbinical and New Testament standards on the conduct of its deliberations and the determination and implementation of its decisions. See notes 23, 40,44, and 59-61, infra and accompanying text.

Araujo expands on Barkan without being any less Erastian. He puts forth four principles for Jesuit law schools: (1) "Jesuit legal education must share in the challenge of coming to know the world in which we as human beings and as lawyers live and work"; (2) educational concern for "the 'whole person'.... as 'ministers of justice,' we must never be blind to the fact that we are not only professionals for our clients; we are simultaneously men and women for others"; (3) the permeation of legal education with love of neighbor (including non-client neighbor); and (4) a commitment to apostolic, "action-oriented" training for lawyers, particularly toward skills for "the development of people learning to live with one another in harmony rather than conflict." Araujo, supra, at 275-76. 
culiar calling of the people of God is to be distinct within civil society and to endure consequent separation from it. Both positions assume, as Robert $\mathrm{E}$. Rodes, Jr. and I have argued, ${ }^{19}$ that a law school maintained by a church can be one of the manifestations of the Church in the world, and that such a manifestation is the principal reason the Church has a law school.

\section{A. The Erastian View}

The Erastian view of what the Church should be, named for a 16th century Swiss physician named Erastus, ponders the problems of the society beyond the Church, from the environment to nuclear weapons to tax policy. It contributes its human and material resources to the goals of the state, and also acts as a religious witness to public discussion of moral issues. It prays for the foreign policy of the state; it blesses the army's tanks in time of war; and it carries the national flag in its liturgical processions.

[It views] the institutional church as one of a variety of institutions through which a Christian society conforms itself to the will of God. ... [It places] the church on a par with the other institutions of society .... [I]t insists that religious ends are to be pursued purposefully and efficiently, just as secular ends are. ${ }^{20}$

But, as much as the Erastian church functionally and historically serves the state, its service will not do as a theological definition. For one thing, that would ignore the origins of the Church as a minority persecuted by the state in the Roman Empire. It would also seem to contradict St. Peter's familiar political principle that Christians must serve God rather than people. ${ }^{21}$ This definition of the Erastian church would incorrectly put the state where God ought to be.

Erastian theology rests instead on an understanding of the civil community (the "wider society" as Rodes puts it) as Christendom. That is, the whole society is Christian-everything from the police department to the public hospital to the religious congregation. The Church is one part of Christendom; it serves the Christian whole, even those members of the wider society who do not consider themselves members of the Church.22 This was true of both the "integral Christendom" of medieval Christianity and "pluralist Christendom" in modern America. ${ }^{23}$ The Erastian church might-as

19. Shaffer \& Rodes, supra note 18, at 6-19.

20. Robert E. Rodes, Jr., The Last Days of Erastianism-Forms in the American Church-State Nexus, 62 Harv. Theological Rev. 301, 304 (1969).

21. Acts 5:29 (New American) ("Better for us to obey God than men!").

22. ROBERT E. RODES, JR., LAW AND MODERNIZATION IN THE CHURCH OF ENGLAND 375 (1991) (third volume in Rodes' series THIS House I HAVE BUILT: A STUDY OF THE LEGal HisTORY OF ESTABLISHMENT IN ENGLAND (3 vols. 1977-1991)).

23. In contrast, Rodes describes primitive Christianity, before the "integral Christendom" of the Middle Ages became possible with the conversion to Christianity of the Roman emperor. Before Constantine's conversion, the Church operated

on the principle that Christ's Kingdom was not of this world. It rendered unto Caesar the things that were Caesar's; as to the things that were not Caesar's, it obeyed God rather than men. It was concerned to order the moral and social lives of its own members .... It waited confidently for God to bring about the consummation of history, but felt no particu- 
it has done in the United States-undertake to train lawyers for the wider (Christian) society in the same way it might undertake to roll bandages for wounded soldiers or establish Reserve Officer Training Corps units on its university campuses.

The Anglican Establishment in England provides the historical and legal model in North America for the Erastian understanding of the "wider society" as Christian, and of the Church as serving Christian society. An Anglican receives baptismal, marriage, and funeral rites all in a parish of the Church of England. Anglicans still debate as political issues questions such as the revision of the Book of Common Prayer or the ordination of women to the priesthood. These debates occur even among duly baptized and married Anglicans who never go to services and won't darken the door of the parish church until they are carried through it to be present for their own funerals. According to Rodes, Christians in the Church of England:

have never accepted the privatization of religion or the secularization of society as necessary concomitants to freedom and pluralism, but have devoted great love and technical skill to providing....

$\ldots$. .

... the church ... a place in public affairs. . . a challenge to prevailing assumptions about war, politics, or economics. ... . continuing recognition of Christian principles as relevant to public debate. ${ }^{24}$

Most (perhaps all) religiously affiliated American law schools that are serious about their heritage are Erastian law schools. If the question is, "Why does the Church have a law school?," the Erastian answer is that the law school serves Christian America. In that way it provides legal education from religious motives. Thus, the law school at Notre Dame points to the motto chiseled over the door to the campus church: "God, Country, Notre Dame." The alternatives for my Catholic law school are to be as secular as if it were supported by the state, or for it to be sectarian. Most religiously affiliated American law schools are secular; perhaps that's what my student

lar responsibility to help Him do so.... [T] he role it assumed in the wider society was one of bearing witness to the coming Kingdom of God and recruiting members for that Kingdom ....

Robert E. Rodes, Jr., Pluralist Christendom and the Christian Civil Magistrate, 8 CAP. U. L. REv. 413, 413 (1979). This might also describe the aspirations of modern "sectarian" Christians, who see the joining of institutional church and empire that occurred at the time of Constantine's conversion to have been an ecclesiological mistake. See JoHN HowARD YoDER, The Hermeneutics of Peoplehood: A Protestant Perspective, in The PRIESTLY Kingdom: Social Ethics as Gospel 15, 15-45 (1984) [hereinafter PRIESTLY KINGDOM] (speaking ecumenically from a sectarian tradition); see also WALTER BRUEGGEMANN, INTERPRETATION AND OBEDIENCE: FROM FAITHFUL READING To FAITHFUL LIVING 41-118, 205-34 (1991) (articulating similar arguments from within the mainline American Protestant church); Stanley Hauerwas \& William H. Willimon, Resident ALIENS: LIFE IN THE ChRISTIAN ColonY 30-48, 69-92 (1989) (arguing for a Church which views itself as a colony of God in this world and teaches its members to act accordingly). All four writers are teachers of Protestant ministers, and all four make their sectarian arguments about what the Church ought to be to all Christians.

24. RODES, supra note 22, at 373 . Rodes describes this as an alternative both to the sectarian church and to the disenfranchisement of religious institutions and communities that occurred in the United States. Id. 
wanted Notre Dame to be. Few-perhaps none-are sectarian; maybe that's what Oral Roberts University wanted its law school to be. The ABA has not insisted that new religiously affiliated law schools be secular. I think, however, that it has told them not to be sectarian. That leaves an ABA-encouraged, Erastian middle ground and exposes the theological implications of the ABA's position.

My student's argument regarding Notre Dame was secular, but it could easily have occupied the Erastian middle ground by arguing that public manifestations of Roman Catholic Christianity at Notre Dame were, or might become, offensive to the Jewish, Protestant, Muslim, Buddhist, or Hindu students we have, and that the Dean should forbid such practices. An Erastian reply from the Dean might have admitted that we should take the feelings of our non-Catholic students into account, but not by pretending that our law school is not a Catholic institution. A sectarian reply from the Dean might have said that we must clearly and frequently proclaim our faith; if pressure from or on behalf of non-Catholics among us interferes with that, we should not admit non-Catholics.

The Erastian law schools are not secular, but they are for the most part indistinguishable from all other law schools. They drift toward the day when some naive believer will describe what they do and wonder why the churches and religious orders that sponsor these schools should bother to continue doing so.25 They do tend, sometimes, to support research and writing that is not of evident interest in secular schools, ${ }^{26}$ but that support is consistent with being secular: No rules at the University of Kentucky or Boalt Hall bar theological scholarship. ${ }^{27}$ Erastian law schools do not significantly inhibit courses and classroom discussion that might be edifying in a Sunday School, that quote Scripture and Luther and Aquinas, and that might, with care, even entertain confessional religious statements. But I have not found any such inhibition in teaching at four secular law schools. ${ }^{28}$ The Erastian law schools sometimes provide convenient opportunities for worship, particularly for members of the denominations that sponsor them, and they sometimes maintain on their faculties members of the clergy. But

25. To some extent this question is put most radically to the schools that are still sponsored by organized denominations or by religious orders, as the denominations and orders themselves become, in Malcolm Boyd's phrase, "chaplain[s] of the status quo." Malcolm Boyd, Ecclesia Christi, in THE UNDERground CHURCH 3, 4 (Malcolm Boyd ed., Pelican Books 1969) (1968). This radical question would be the one Hauerwas and Willimon, and Brueggemann would want to ask if they were to consider legal education. See BrueggemanN, supra note 23; HaUerwas \& Willimon, supra note 23.

26. See Thomas L. Shaffer, Mission of a Church-Related Law School: The Catholic Tradition, 22 VAL. U. L. REV. 669, 671-72 (1988).

27. For example, Professor John H. Garvey of Kentucky has been active as a believer doing church-state scholarship. See, e.g., John H. Garvey, A Comment on Religious Convictions and Lawmaking, 84 MiCH. L. REV. 1288 (1986); John H. Garvey, Churches and the Free Exercise of Religion, 4 Notre Dame J.L. Ethics \& PUB. Pol'y 567 (1990); John H. Garvey, Free Exercise and the Values of Religious Liberty, 18 CoNN. L. REv. 779 (1986). At Boalt Hall, Professor (now Judge) John T. Noonan, Jr. conducted extensive scholarship in theological areas. For an indicative list of his major works, see Shaffer, supra note 26, at 671-72.

28. Washington and Lee, the University of Virginia, U.C.L.A., and the University of Maine. 
secular schools are usually near places of worship and also hire clergy who are lawyers.

Ultimately, the question my student asked suggests that there is no practical difference between an Erastian school and a secular school. Yet, Erastian schools may have this answer: They sponsor an intellectual interest in matters that are religiously important. Perhaps my own Notre Dame goes as far as any toward what seems to be a philosophy of Erastian intellectual convenience when it says in its catalogue that "moral and religious questions are important; no one need apologize for raising them or for taking them seriously when others raise them ... [and] everyone who comes here should be encouraged to explore basic personal commitments and to relate them to what is learned here . ..."29 This is a claim of broadened educational relevance. It implies that secularism is a dogma that excludes important lines of moral inquiry and formation, because these lines are or might be religious, and that the Erastian commitment preserves those lines of inquiry and formation as both religiously and civilly important.

A focal issue on this point is coercive violence. The Erastian church does not see itself merely as serving the state, but it often becomes a cheering section for state violence. ${ }^{30}$ Consider the tombs of imperial conquerors in Westminster Abbey, of officers who died in India and in the Boer War, or the Stars and Stripes to one side of the pulpit or altar in most American places of worship. Nonetheless, the Erastian church sometimes daringly, or even courageously, bears religious witness against dominant political agendas. Its pondering of the political and legal problems of its society purports, after all, to be a pondering in the Church. And so it can produce condemnations of political and economic policy, such as the Roman Catholic Bishops' letter on American capitalism ${ }^{31}$ and the statements we heard in the 1980s from virtually all Christian churches questioning the development of nuclear weapons. ${ }^{32}$ The Pastoral Constitution on the Church in the Modern World, ${ }^{33}$ a principal document of the Second Vatican Council, along with much of

29. UNiversity of Notre Dame LAW School, Bulletin of INFormation 2 (1993-94).

30. The distinction in terms of violence-lethal state power-is important, if only because the one dependable mark of those Christian traditions that are called sectarian is that their members refuse to kill at the behest of the state. See, eg., Yoder, The Kingdom As Social Ethic, in Priestly KINGDOM, supra note 23 , at 80.

31. National Conference of Catholic Bishops, Economic Justice for All: Pastoral LetTer on Catholic Social Teaching aNd the U.S. Economy (1986) (calling for greater weight to be placed on the rights of the poor, and on the community as a whole, in economic decision making).

32. See, e.g., National Conference of Catholic Bishops, The Challenge of Peace: GOD's PROMISE AND OUR RESPONSE (1983) (calling for international negotiations for peace and educational refocus as alternatives to the proliferation of weapons of mass destruction, and declaring the Bishops' opinion that the use of nuclear weapons-but not the use of other methods of lethal violence-is immoral).

33. Second Vatican Council, Gaudium et Spes: Pastoral Constitution on the ChURCH IN THE MODERN WORLD (1965), reprinted in RENEWING THE EARTH: CATHOLIC DocuMents on Peace, Justice AND Liberation 178 (David J. O'Brien \& Thomas A. Shannon eds., 1977) [hereinafter GAUDIUM ET SPES]. 
Protestant and Roman Catholic liberation theology, ${ }^{34}$ develops this possibility in theological terms. The Latin title of the pastoral constitution, Gaudium et Spes, comes from its opening words: "The joys and hopes, the griefs and the anxieties of ... this age ... these too are the joys and hopes, the griefs and anxieties of the followers of Christ."35 If religiously affiliated American law schools do not develop analogous theological leadership in curriculum and course content-and, by and large, they do not-then they are vulnerable to criticism from their Erastian sponsors, criticism that many of us who labor in such places would welcome and support.

Still, state violence is the focal issue: In the village of Saint Radegund, Austria, there is a cemetery near the parish church. Fifty-three sons of that village, who fought and died in the German Army in World War II, are buried there. So is the parish's only conscientious objector, Franz Jägerstätter, a peasant, husband, father, Christian, and one-time parish sexton. The institutional Roman Catholic Church in Austria supported the Germans in World War II, virtually without dissent. But Jägerstätter, against the advice of his pastors, refused to report for induction into the German Army on clearly and sometimes eloquently stated traditional Roman Catholic religious grounds. He was beheaded for his resistance to the war effort. His ashes lie in the part of the cemetery reserved for those who died in the war, and his name is listed on the war memorial in the parish church. ${ }^{36}$ From an Erastian point of view, both he and his neighbors who fought for Hitler were faithful sons of the Church.

\section{B. The Sectarian Alternative}

Being sectarian is a clear alternative for religiously affiliated law schools. ${ }^{37}$ The sectarian theology of the Church does not hold the community of the faithful responsible for the wider society or seek to be in charge of society as a whole. Given the nature of what it calls "the World," it is dis-

34. Shaffer \& Rodes, supra note 18, at 5; Thomas L. Shaffer, Jurisprudence in Light of the Hebraic Faith, 1 Notre DAME J.L. ETHICS \& PUB. POI'Y 77, 99-106 (1984).

35. GAUdium ET SPES, supra note 33 , at 178.

36. For a moving portrait of Jägerstätter, see GoRDON C. ZAHN, IN SolITARY WITNESS: THE Life aNd DeATH of Franz JägerstätTer (1964). See also Thomas L. Shaffer, ON Being A CHRISTIAN AND A LAWYER: LAW FOR THE INNOCENT 207-16 (1981).

37. See Symposium, Sectarianism, 44 THEOLOGY TODAY 69 (1987) (discussing sectarianism in its narrower theological sense, mostly depending on the ecclesiological typologies of Ernst Troeltsch and $\mathrm{H}$. Richard Niebuhr). In his symposium piece, Stanley Hauerwas framed the issue as the extent to which "sectarian" describes religiously-based dissent from the dominant values of the culture. Stanley Hauerwas, Will the Real Sectarian Stand Up?, 44 Theology TODAY 87, 88 (1987). He declines to be a sectarian, in that sense, because he does not believe that current American culture can be described clearly enough to make dissent from it coherent. Id. If one can describe American culture-and, perhaps, the ABA's focus on diversity as a norm is an attempt to do so-a sectarian American law school can be understood as one maintained by a religious group that is willing to be distinctly religious. Accordingly, religious legal educators would not seek diversity as much as they would seek doctrinal agreement among those eligible to join in dissent from the dominant culture. I prefer to understand sectarian American law schools as maintained by religious groups that consider approval by the wider society irrelevant to their ethical and political mission. As a claim, perhaps, but more as a consequence, I distinguish this as a sufficient working definition for what I mean by "sectarian." See note 18 supra. 
tinct, not by choice, but because the World pushes it aside. Its moral deliberations concern obedience to its Lord; it serves the wider society when such service comports with what it perceives to be its religious purposes (as with the admonitions in the Torah and New Testament to serve one's neighbors). Regarding political and legal activity, as a Mennonite legal aid lawyer once told me, "There are some things we don't do." Like the Prophet Jeremiah, those in the sectarian church seek "the welfare of the city to which [God] ha[d] exiled them."38 They do not seek to subvert the purposes of the state, but, like the primitive Jewish Christians described in the Acts of the Apostles, they accept the consequences of their priority to serve God rather than people. ${ }^{39}$

Within an inevitable selectivity, though, serving God is serving peopleother people, outsiders, even the "public":

That Jesus Christ is Lord is a statement not about my inner piety or my intellect but about the cosmos. Thus the fact that the rest of the world does not yet see or know that destiny to which it is called is not a reason for us to ... broker ... some lower common denominator or halfway meeting-point, in order to make that divine destination ... more acceptable or more accessible. The challenge to the faith community should ... be ... to purify and clarify and exemplify it so that the world can perceive it to be good news without having to learn a foreign language. 40

Both the Quakers and the Anabaptists, which include the Amish, the Mennonites, the Seventh Day Adventists, and the Church of the Brethren, prominently exemplify this theology. But it would be a mistake to confine the theological (ecclesiological) argument to those denominations. As Karl Barth, theologian to mainline Reform (Calvinist) Protestantism, said, with particular reference to the Church's demonstration of what the law should be:

[W]orldly law . . . has already ceased to be the last word[;] . . there are other possibilities, not merely in heaven but on earth, not merely one day but already, than those to which [the world] thinks that it must confine itself in the formation and the administration of its law.... If the [Church] were to imagine that the ... sanctification of humanity accomplished in Jesus Christ were restricted to itself and the ingathering of believers, that it did not have corresponding effects [outside the walls of the Church], it would be

38. Jeremiah 29:7 (New American).

39. Erastians and sectarians may, of course, engage in the same civil endeavors and sign the same petitions. The distinction lies in sectarians' determinations that (1) the community of importance is the community of the faithful; (2) the community of the faithful is precise as to who are members and who are not; (3) it will not use coercive force either within its own processes or in service to its neighbor; and (4) outsiders will eventually react to it with hostility, as St. Paul said they would when he wrote of "the principalities and powers, the rulers of this world of darkness." Ephesians 6:12 (New American). For systematic development of these themes, see YODER, supra note 30, and Stanley Hauerwas, The Peaceable Kingdom (1983).

40. John Howard Yoder, First Fruits: The Paradigmatic Role of God's People-An Angle on "The Public Good," Lecture at the Christian Theological Seminary of Indianapolis 6 (Oct. 4, 1992) (transcript on file with the Stanford Law Review); see id. at 8 ("The order [i.e, the law] of the faith community constitutes a public offer to the entire society."); see also JOHN HOWARD YODER, THE Christian Witness to The State (1964). 
in flat contradiction to its confession of its Lord. ${ }^{41}$

Nonetheless, the purposes of the church and the purposes of the state (the law) almost always diverge. The focal example is, still, that most sectarian Christians still refuse to kill people.

But there is more to the sectarian theology of the Church's history than pacifism. In early 16th century Zurich, the Anabaptists broke away from Ulrich Zwingli's branch of the Protestant Reformation. Initially, and principally, they dissented from Zwingli's seeking for believers the protection of the civil authorities. "They advocated instead ... a life of uncompromising discipleship, declining to rely on political power for the maintenance of religion and refusing to bear arms, to use coercion of any sort, to appeal to the courts or to swear oaths." 42 As a consequence, other Christians, both Protestants and Catholics, ruthlessly persecuted them. Virtually all of the Anabaptists of Zurich were killed. ${ }^{43}$

I don't know of any plans to establish a Mennonite law school, although there are many Mennonites in the American legal profession. But if the sectarian view argues for what the Church ought to be, ${ }^{44}$ rather than simply defining what it is, then sectarianism presents a model for what religiously affiliated law schools ought to be and engages the ABA's encouragement of the Erastian and secular alternatives. In this light, the sectarian view offers a coherent theological argument for and within religiously affiliated American law schools. Such an argument in fact often surfaces, albeit timorously, in deliberations within those schools and within their sponsoring universities.

How might the sectarian argument play out in a religiously affiliated law school? To what might such a school aspire in the lives and the religious witness of its graduates-who would not be diverse, who would have come to the Church to study law, who would aspire to practice law going out from the Church, and to return to figure out how to practice law? Four character-

41. 4 Karl Barth, Church Dogmatics: The Doctrine of Reconciliation 721-23 (G. W. Bromiley \& T. F. Torrence eds. \& G.W. Bromiley trans., 1958). I am indebted to my colleague John Howard Yoder for the thought, the reference, and an eloquent extension of the argument:

[T] he alternative which Barth posits over against apologetic inverse solipsism is confession.

To confess that Jesus Christ is Lord makes it inconceivable that there should be any realm where his writ would not run. That authority .... cannot be excluded by being declared to be alien, or "private" or "personal," but only by not (i.e., not yet) being heard.

Yoder, supra note 40, at 6.

42. Wilhelm Pauck, Reformation, in A Handbook of Christian Theology: Definition Essays on CONCEPTS and MOVEMENTS of Thought in CONTEMPORARY Protestantism, supra note 2, 299, 307-308.

43. Id. at 308.

44. For examples of how we should change the Church or how the Church should either transcend or change the world, see BRUEGGEMANN, supra note 23, at 161-83 (calling for a transformative agenda for pastoral care); HAUERWAS, supra note 39; HAUERWAS \& Willimon, supra note 23, at 15-29, 43-48 (writing of the need for a "confessing" church which counters prevailing social norms); William H. Willimon, Peculiar Speech: Preaching to the Baptized (1992) (challenging the Church to speak to those who have been called to it: the baptized); and Timothy P. Jackson, The Disconsolation of Theology: Irony, Cruelty, and Putting Charity First, 20 J. Religious ETHICs 1 (1992) (placing of a priority on charity as an affirmation of life and of the living God). See also Karen Baker, Legal Ministry: To Heal and Empower, HaRv. Divinity Sch. Bull., June-July 1982 , at 6. 
istics come to mind. First, the sectarian law school would be a communal prospect. Second, it would view the practice of law, for a believer, as a commissioned ministry in the world. ${ }^{45}$ Third, such ministry would depend on a certain, dare I say, infallible, assurance. Fourth, the school's ethic would address specific, particular professional behavior.

\section{Communal.}

In a sectarian law school, students receive their legal education in and from the community of the Church. ${ }^{46}$ They learn from and within a tradition of value-from the perspective of Christian theology. The sectarian law school's theological knowledge-its understanding of God-is, as Bonhoeffer said, the memory of the Church. ${ }^{47}$ God has spoken and speaks to the people of God as a people. The process of making sense of God's words occurs in the Church. For instance, the scriptures tell us to be servants to our neighbors. A lawyer understands this scriptural mandate from the discussions in the Church about what servanthood means. The lawyer does not ask the world what servanthood means, because Jesus has already told her that the world is confused on the point. The world talks about benefactors, rather than servants. 48

This communal direction may differ from other communal traditions. It may differ even more from the individualistic ethics, still dominant in American legal education, that claim no community at all. 49 When William $\mathrm{H}$. Willimon, who trains Methodist ministers at Duke, talks about the Church, he speaks as a sectarian and as one who seeks to train sectarians. He uses

45. "Ministry" here means service to one's neighbor. Because sectarians place primary emphasis on the processes of the community of believers-the congregation-one should note that the more precise New Testament meaning of ministry relates to those processes and to the way believers in the congregation minister to one another. The service-to-neighbor understanding of ministry owes more to Martin Luther's doctrine of vocation-seeing every Christian's work in a gainful occupation as service to God and humankind-than it owes to the congregational ecclesiology of the Anabaptists. John Howard YODER, THE FULLNESS OF Christ: PAUL's REVOLUTIONARY VISION OF UNIVERSAL MiNISTRY 39-40, 46 (1987).

46. This is not necessarily a conventional religious congregation (although it may be). Such a community might meet in a Methodist church, a Catholic one, or in a synagogue or temple, but the Church also meets elsewhere. It often meets in a law school or in the hallway outside a courtroom. A Jewish quorum is two for discussion, ten for worship. See SAMUel S. Cohon, Judaism: A WAY OF LIFE 355 (1948). We Christians need two or three for either purpose. See Matthew 18:20.

47. Clyde E. Fant, Bonhoeffer: Worldly Preaching 27 (1975).

48. Cf. Luke 22:25-26 ("Earthly kings lord it over their people. Those who exercise authority over them are called their benefactors. Yet it cannot be that way with you.").

49. Tom Buford, a professor of religious ethics at Furman University, summarizes this individualist credo:

[A]n important characteristic of the twentieth century is that there is no generally agreed upon ultimate principle, body of knowledge, or power... to which all of us ought appeal in settling disputes among competing goods to determine which is correct .... [O]ur only recourse ... is to appeal to procedural justice to decide whether our view ... is too narrow or the proposed good is unjust. The flourishing of competing goods refereed by procedural justice is an instance of an open, pluralistic society.

Tom Buford, Response, THE CREsSET (Valparaiso University, Valparaiso, Ind.), June 1992, at 10, 11. 
words such as distinct, deviant, subversive, and peculiar. ${ }^{50}$ Scriptural words for the Church include kingdom, New Jerusalem, holy people, messianic, and a nation of priests. Sectarians talk about being lawyers in and from such a community.

In the sectarian religious community, discussion is a communal instrument of moral reasoning. ${ }^{51}$ For example, we held an "institute" on legal ethics for alumni at Notre Dame last summer. My colleague Barbara Fick discussed the legal recourse, if any, under the Americans with Disabilities Act for clients with AIDS, clients with physical deformities, obese clients, and clients who were alcoholics. Because discussion took place in the Church, we talked about these people as children of God, not as objects of the law. The distinct communal nature of our discussion changed the substance of what we discussed. Mainline American legal ethics tends to regard clients as sources of corruption. We tried, however, to discuss these clients scripturally-as the people the Hebrew Prophets and the Rabbis told us lawyers to prefer, to put first, to care for, and to become like.

Years ago at an AALS meeting, Clare Dalton, law professor and gentle feminist, made the point that feminist ethics, like religious ethics, is communal. She told of a third-grade child who was, as they say now, hearing impaired. Because the law described that child as a student with rights, the possibility arose for mandating classroom interpreters and mechanical aids at public expense. Professor Dalton reported that this view served both as a way to describe the child's situation and as a way for the community itself not to respond to it, because interpreters and machines were not available. What happened instead was that this community of third-graders decided to learn sign language. All of them. All together. Who had a right to demand that communal response? Who had a right to interfere with it?

\section{Commissioned.}

Lawyers who go out from the community of the faithful as ministers go with a commission from that community. They go with authority. Consider, for instance, the rabbinical tradition in Talmudic Judaism, which encourages discussion and argument. In its communal instruments of moral reasoning, it disdains any attempt to silence people. But the rabbinical tradition reaches conclusions to guide the political and moral life of its community. Conclusions bring problems. Practical conclusions following spirited arguments mean that somebody loses; the question was what to do about the losers. The Rabbis decided to preserve the arguments they rejected. Preservation is part of Judaism's astounding bibliographical enterprise. They preserve the losing argument so that it may be revived and win at some future time. But for the present, after the communal instrument of moral reasoning has had its way, the losing argument cannot be put into practice. The community honors the loser, even as it acts with sure and certain authority to

50. Willimon, supra note 44, at 4, 9, 50-53, 58, 107.

51. See YODER, supra note 23 , at 24-29. 
reject his argument. 52

The Christian model for civil lawsuits, contained in the eighteenth chapter of St. Matthew's Gospel, provides another example of the authority of the commissioned lawyer-minister. In this model, a member of the community first confronts the judgment of the community both privately and communally. ${ }^{53}$ If the errant or erroneous member of the community refuses to follow that judgment, the community "treat[s] him as ... a Gentile or a taxcollector." 54 Apparently, the errant member is not only told he is wrong but is kicked out of the community as well. Of course, a Christian has to think also about how Jesus dealt with tax collectors, pagans, lepers, Samaritans, and others cast out by the community. This part of ministry, however, does not dilute the authority of the community to make moral judgments for its members. Nor does it dilute the authority of the minister who acts on the community's commission. 55

The Rabbis of the Talmud claimed to resolve questions of Jewish law under a mandate from the Lord-the Oral Torah, which came to them from Mount Sinai as certainly as the written mandate Moses put into Scripture. The representatives of the Church who deal with the errant member, under the commission described in the Gospel of Matthew, act with similar authority. Jesus said he was giving them the keys to the Kingdom. ${ }^{56}$ They said, when they had come to a decision, "It is the decision of the Holy Spirit, and ours too." 57

\section{Infallible.}

By "infallible," I mean that the communal commission under which the lawyer-as-minister acts is dependable or, better yet, indefatigable. I do not mean the infallibility the first Vatican Council claimed for the Bishop of Rome. That was an authority over propositions. ${ }^{58}$ The infallibility I am claiming for the communal instrument of moral reasoning lies not in propositions, but in process. Roman Catholics do not claim a monopoly on this sort of infallibility. When the Rabbis rejected a losing argument and preserved it, they spoke not with the voice of God, but at the behest of God. Thus, they spoke with divine authority. The Rabbis were clear about that-

52. See Eliezer Berkovits, Not in Heaven: The Nature and Function of HalakHa 47-49, 79 (1983); ROgER Brooks, THE SPIRIT OF THE TEN COMMANDMENTS: SHATTERING THE MYTH OF RABBINIC LEGALISM 20, 22 (1990) ("God's decrees underlie and provide the authority for rules derived through halakhic means ...."). I am indebted to Professor Brooks, who taught me and my Notre Dame law students about this tradition, and about much else in Judaism.

53. Matthew 18:15-16.

54. Id. at 18:17 (New American).

55. See L. GREgory Jones \& Stephen E. Fowl, ReAding in CoMmunion: SCRIPTURE AND ETHICS IN CHRISTIAN LIFE 135-59 (1991).

56. Matthew 16:19.

57. Acts 15:28 (New American).

58. The Pope has only used it twice, on matters so obscure that few people know what they were. See 2 RICHARD P. MCBRIEN, CATHOLICISM 835-42, 879-97, 1004 (1980) (involving the dogmas concerning the immaculate conception of Mary, the mother of Jesus, and her assumption into heaven). 
much clearer than Roman Catholics are about papal infallibility. 59

If true to itself, the religious tradition will always claim the dependability of divine authority. By doing so, the tradition says that it will not be defeated by its own mistakes. People who act from faith understand that they can afford to be wrong. Sin boldly, as Martin Luther put it..$^{60}$ But, even more important for lawyers relying on the community as an instrument of moral reasoning, the community can afford to be right. No one can ever be entirely confident that his perception is the truthful one, or her moral advice to clients is the best possible moral advice. Faith, however, gives a confidence that allows the believer to go on as if she were certain, at least for the present. Whether that assurance is justifiable depends on whether the right processes are followed in arriving at it. ${ }^{61}$

Unless a sectarian law school is willing to claim infallibility for its processes, it will probably not be truthful enough to support its graduates when they go out from the Church to practice law. It will also probably never attract or deserve words such as deviant or subversive, because it will so often be talked out of confronting power. Moreover, unless the school claims infallibility, it will deceive itself about the oppressive tendencies that are largely supported in church-related American law schools. ${ }^{62}$ It will so long and so well be the lobbyist and the politician that it will forget how-to use the old, good, biblical word for this-to be prophetic.

\section{Specific.}

A dismal falsehood, cherished by the mainline Christian church in America, states that the memory of the Church and the scriptural canon the

59. Yoder describes the (for present purposes) similar process of the local congregations of the Radical Reformation as "the hermeneutics of peoplehood." YODER, supra note 23, at 15. He suggested that what I am trying to do with this word "infallible" is to describe a communal decision that will be implemented until further notice. Letter from John H. Yoder to Thomas Shaffer (June 22, 1992) (on file with the Stanford Law Review).

60. THE OXFORD DictionaRY OF QuOTATIONS 432 (1992) (citing a letter Luther wrote to Melanchton in 1521). The translator used "strongly" rather than "boldly," but "boldly" is the word usually chosen. See generally 2 Helmut Thielicke, Theological Ethics 642-48 (William H. Lazareth ed., 1969) (discussing the Church's role in pondering right and wrong).

61. An issue arises about the efficacy of a dialogue between the civic discussion which is the main business of the law and the discussion in the Church which I am describing here. Yoder seems to teach that the sectarian conversation can contribute to the civic discussion, but not be helped by or influenced much by it. See, e.g., JoHN Howard Yoder, The Christian Case for Democracy, in Priestly Kingdom, supra note 23, at 151; John Howard Yoder, Civil Religion in America, in PRIESTLY KINGDOM, supra note 23, at 172. In a more recent, unpublished work, however, he seems not to want to underline a difference between the communities any more than his doctrine requires. For instance, he says that "the faith community [is] connatural with the wider society, as a result of which the church's clearest word to the world"-as well, perhaps, as what it hears the world say"is inseparable from the church's own integrity." Yoder, supra note 40 , at 12. For Yoder, the Church must know what its mission is. Brueggemann, on the other hand, speaks more as a mainline churchman than as a sectarian. He argues that the civic conversation (which he calls the conversation "on the wall") can influence and even correct the conversation in the Church (the conversation "behind the wall"). BRUEGGEMANN, supra note 23, at 41-50 (following an image he gets from 2 Kings 18-19).

62. Most of these oppressive tendencies stem from the corrosive effect of money in law schools, among law students, and in law firms. 
Church preserves have no bearing on politics, law, or ethics and do not speak clearly to social problems. The moral teachings of Jewish and Christian scripture, according to this dismal falsehood, only concern being nice to one another and obeying a few unavoidable personal moral injunctions. They do not address how to speak out and act out in a lethal political world.

In truth, religious sources of social, political, and legal morality are painfully specific. They point, often clearly, to specific actions at particular times and places. Jesus entered Jerusalem naked to his enemies. St. Francis returned even the clothes from his back to his wealthy father. Luther nailed his bold theological theses to the church door. Franz Jägerstätter refused to report for induction into the German army. These acts, to paraphrase Yoder, were very broad because they were very concrete. ${ }^{63}$ The problem for us believers is that we do not like them. And so the main business of Christianity in America has mostly concerned how to make America work and how to make religion out of American liberal democracy, rather than how to make Christianity work. ${ }^{64}$ The Church in America has too fondly embraced Jefferson's notion of America as God's New Israel.65 Examples of such thinking stretch from the day the Puritan divine spoke of his "new world" as a city on a hill, ${ }^{66}$ through Protestant religious blessings for the imperialistic "Manifest Destiny" of American military and foreign policy in the nineteenth century, ${ }^{67}$ through the recent notion that the United States has a mandate from the Lord to preside with lethal force over a "new world order." 68

I don't know where the third-grade teacher about whom Clare Dalton

63. Yoder, supra note 40 , at 9 (emphasis added). Christian love specifically differs, in terms of both social ethics and applied ethics in the professions, from the secular jurisprudence and ethics that privatize religion, as in Robert Rorty's doctrine of lonely individualism and ethical irony, and Judith Shaklar's limitation of interpersonal morality to the avoidance of cruelty. See Jackson, supra note 44 (rejecting Rorty's and Shaklar's approaches, and defending Christianity's putting charity first among the virtues); William H. Willimon, The Effusiveness of Christian Charity, 69 THEOLOGY TODAY 75 (1992) (criticizing a move toward a means-end view of the way Christian charity should focus on social action).

64. See Stanley Hauerwas, Against the Nations 122-31 (1985) (responding to Richard Neuhaus' essay, Christianity and Democracy: A Statement of the Institute on Religion and Democracy, CENTER J., Summer 1982, at 1).

65. In commenting on an earlier draft, my colleague Rodes noted that, to be fair to Jefferson, one should point out the dual nature of the Israelite analogy. Israel suffered when it failed to obey God. We can suffer, too (if we have not already). Of course, my point here is that the mainline church has latched on to only part of Jefferson's thought on this issue.

66. John Winthrop, Modell of Christian Charity, excerpted in 2 RoBERT C. WiNTHRop, LIFE AND LETTERS OF JOHN WiNTHROP 18-20 (DaCapo Press 1971) (1867).

67. JAMES MACGREgor BURNS, The WORKSHOP OF DEMOCRACY 340-41, 400 (1985).

68. Cf. Dan Balz, Bush Praises Gulf Forces, Calls for Mideast Peace: President Urges Hill to Back Domestic Agenda, WASH. Post, Mar. 7, 1991, at A1 (describing President Bush's State of the Union Address as a "patriotic celebration of the allied victory over Iraq"); Jack Nelson, Willingness to Use Force Marks Bush's 1st 2 Years, L.A. Times, Mar. 15, 1991, at Al (suggesting that President Bush "sees the use of force not as a last resort but as a standard option to employ whenever he thinks vital American interests are at stake and peaceful means are too weak or to slow to protect them"); John E. Yang, Bush Defends Non-Intervention in Iraq: President Begins Speech Campaign to Define "New World Order", WASH. POST, Apr. 13, 1991, at A27 (calling "the 'quest for a new world order $\ldots$ a challenge to keep the dangers of disorder at bay'"). 
spoke got the idea that all the students in her class could learn sign language to deal communally with one child's difficulty in hearing the other children. She may have gotten it from one of the children; she, or the child she got it from, may have gotten it from Sunday School. In any case, the solution was at least as specific as anything John Rawls might have proposed for the situation.

\section{Consider another example, from Branch Rickey:}

The greatness of Jackie Robinson came in his capacity to turn the other cheek. 'Punch by punch' was by inheritance, by experience, and by desire, Jackie's quick and natural reaction to attack. ... It took an intelligent man to understand the challenge. It took a man of great moral courage to accept it and see it through. He was both. ${ }^{69}$

The moral challenge here was painfully specific to both the behavior it required of Jackie Robinson and to his understanding of the consequences of such behavior. It could not have been easy. As Talmage Boston noted, "Robinson endured verbal abuse, hate letters with death threats, pitches aimed at his head (in the days before batting helmets), gashes from spikeshigh baserunners, and every possible form of hostility."70 Robinson's response was in any case clear and specific.

The vast majority of lawyers may never face what Jackie Robinson faced. But lawyers do face moral challenges every day. Take, for example, the problem of "Rambo" lawyers, who abuse discovery, disrupt negotiation, and do what they can to frustrate legal process without seriously breaking any of the rules set up for them by legal ethics. At last summer's alumni institute at Notre Dame, several professors and several practicing lawyers had something to say about Rambo lawyers. I was struck by the professors' desire to deal with the Rambos by inventing new rules for the state to enforce, and by judges interpreting old ones differently. The law professors were not content with what was going on in the Church.

The practitioners, who face Rambo lawyers and the temptation to join them, and who also understand something about ministry in the law, told us that they deal with Rambos by enduring them. It was they who seemed to understand that biblical servanthood is specific. They seemed to know, beyond and beneath ethical theory, that servanthood involves suffering, and that it holds out the possibility of converting even a Rambo." "Yet I am in your midst," Jesus said, "as the one who serves you."72 It seems Jesus had in mind a specific occupation, as well as a specific way to be. Jesus also paraphrased, in another piece of specific ethical advice, a maxim from the

69. Talmage Boston, Jackie Robinson and the Papini Doctrine, ElysIAN FIELDS Q., November 1992, at 41 (All Star Issue) (quoting Branch Rickey).

70. Id.

71. Yoder, in a note to me, said: "[Your alumni] deal with Rambos by enduring them. That should include naming them, denouncing them publicly, and organizing communal support for the victims, even celebrating the victims; to say that 'inventing new rules against Rambos' is not enough is true but is not enough." Letter from John H. Yoder to Thomas Shaffer (Dec. 29, 1992) (on file with the Stanford Law Review).

72. Luke 22:27 (New American). 
Book of Proverbs. Hebrew Scripture says: "If your enemy be hungry, give him food to eat; if he be thirsty, give him to drink; [f]or live coals you will heap on his head, and the Lord will vindicate you."73 Rabbi Hanina bar Hama said, as, I think, Jesus did, that the meaning of the verse from Proverbs is conversion. Rabbi Hanina interprets the verse to mean that "even if the enemy came to your house to slay you, and he is hungry or thirsty, give him food and drink; for thereby God will reconcile him to you."74

It is no doubt the case here, as it is with much of the politics and ethics of scripture, that scriptural ethics are in tension between largeness of vision and a Jewish passion for particularity. ${ }^{75}$ But those who say that the primary religious sources do not provide specific ethical guidance are missing both the vision and the particularity.

\section{CONCLUSION}

I suppose a group of religious people has a reason for maintaining a school for the training of lawyers. I have meant to suggest that its reason is in some deep, maybe mysterious and more than historical, sense religious and theological, theology being the discipline which explicitly takes God into account. A religiously affiliated law school cannot account for itself theologically by being or aspiring to be like law schools maintained by the state or by non-religious private sponsors. It cannot be faithful to itself and also be secular. To the extent that a religiously affiliated law school is content with being secular, it denies its heritage and its purpose. Most religiously affiliated law schools in the United States are in practice secular. I do mean to suggest, by way of what Aquinas called fraternal correction, and Barth called conditional advice, that these schools, their universities, and their law faculties are not faithful to themselves and that what they are doing denies both their heritage and their purpose. It is hard to know why their religious sponsors continue to maintain them.

The theological rejection of the secular alternative leaves two theological possibilities. I have identified one of these with the obscure adjective Erastian and the other with the contentious adjective sectarian. The Erastian schools aspire to serve. Their theology is most consistent as a religious practice when the society they claim to serve is perceived to be what medieval Europe called Christendom. Erastian law school theology is coherent; its history is rich; its hope is incredible (as hope often is). Erastian law school theology, however, seems to rely on the survival of a Christian social order that is not evident in North America, not dependable, and maybe not even capable of coherent description. It tends in practice to justify whatever the "wider society" does, however lethal, un-Jewish, and un-Christian the popular project is or is, with the benefit of historical judgment, seen to have been.

73. Proverbs 25:21-22 (New American).

74. Cohon, supra note 46, at 214. For a fuller development of this theme, see THomas L. Shaffer, Faith aNd the Professions 39-70 (1987).

75. Walter Brueggemann, Praying the Psalms 63-64 (1986). 
I propose the sectarian theology which I have described as a religiously sound alternative to secularism because it avoids these two objections to Erastian law school theology. My advocacy of the sectarian alternative is political, in that a group of religious sponsors could have such a law school if it is willing to try, and willing as well to countenance the consequences of its faithfulness. My suggestion is theological, in that it reflects what I understand to be the memory both of the Church and of Judaism. ${ }^{76}$ My hope (possibly incredible) as to the theological agenda is that this present effort of mine will provide something to talk about among believers who think they are in their own law school.

76. For a more jurisprudential expansion of this thought, see Thomas L. Shaffer, The Church and the Law, in - (Andrew W. McThenia, Jr. ed., forthcoming 1993) (a collection of works in honor of the late William Stringfellow). For a similar jurisprudential treatment applied to the practice of religiously affiliated law schools, see Edward McGlynn Gaffney, Jr., The Gospel in the Law: Jurisprudence of Pastor Neuhaus, 14 VAL. U. L. REV. 15 (1979). 


$$
\times
$$

